\title{
MANAJEMEN DAKWAH PROGRAM KISAH MENAWAN SANG TELADAN DI RADIO RODJA 75,6 AM BOGOR
}

\author{
Muhammad Samih Rozin, Fatmawati \\ Fakultas Ilmu Dakwah dan Komunikasi, UIN Syarif Hidayatullah Jakarta \\ Email: samihrozin@gmail.com; fatmawati@uinjkt.ac.id
}

\begin{abstract}
The development of today's communications media has enabled people around the world to communicate with each other. This study aims to find out how the preproduction process of the Captivating Story of the Exemplary Program, how the process of implementing the production of the Captivating Story of the Exemplary, and how the evaluation process in the Program Story of the Model in Radio Rodja. This research uses qualitative approach. The research method used by the author is descriptive analysis. Descriptive method aims to describe the systematic facts or characteristics of a particular population or field in a fact and accurate. In other words, this method analyzes and interprets the meaning of the data. In the program of the captivating story of the exemplar through several stages: pre production includes: ideas, format planning, broadcast materials, performers, program name, and time of broadcast. The production process includes: the implementation of broadcasting, production materials, production executors, and facilities and infrastructure. Post production is weekly evaluation and the whole team.
\end{abstract}

Keywords: Radio, Production Process, Da'wah Program, Story Example, Children

\begin{abstract}
Abstrak
Perkembangan media komunuikasi dewasa ini telah memungkinkan orang diseluruh dunia untuk saling berkomunikasi. Penelitian ini bertujuan untuk mengetahui Bagaimana proses pra produksi Program Kisah Menawan Sang Teladan, Bagaimana proses pelaksanaan produksi Program Kisah Menawan Sang Teladan, dan Bagaimana proses evaluasi dalam Program Kisah Menawan Sang Teladan di Radio Rodja. Penelitian ini menggunakan pendekatan kualitatif. Metode penelitian yang digunakan oleh penulis adalah analisis deskriptif. Metode deskriptif bertujuan melukiskan secara sistematis fakta atau karakteristik populasi tertentu atau bidang tertentu secara fakta dan cermat. Dengan kata lain metode ini menganalisis dan mengintepretasi tentang arti dari data tersebut. Dalam program kisah menawan sang teladan melalui beberapa tahap yaitu pra produksi meliputi: ide, perencanaan format, materi siaran, pengisi acara, nama program, dan waktu siaran. Proses produksi meliputi: pelaksanaan siaran, materi produksi, pelaksana produksi, serta sarana dan prasarana. Pasca produksi yaitu evaluasi mingguan dan seluruh tim.
\end{abstract}

Kata Kunci : Radio, Proses Produksi, Program Dakwah, Kisah Teladan, Anak-anak 


\section{A. Pendahuluan}

Perkembangan media komunuikasi dewasa ini telah memungkinkan orang diseluruh dunia untuk saling berkomunikasi. Hal ini dimungkinkan karena adanya berbagai media (channel) yang dapat digunakan sebagai sarana penyampaian pesan. Media penyiaran, yaitu radio dan televisi merupakan salah satu bentuk media massa yang efisien dalam mencapai audiensnya dan dalam jumlah yang sangat banyak, oleh sebab itu sangat relevan untuk diterapkan dalam penyampaian ajaran agama Islam. Kelebihan dari media massa elektronik radio siaran ini adalah berada dimana saja. Kemampuan yang tinggi untuk menjangkau setiap pendengarnya yang sedang melakukan kegiatan-kegiatan lainnya sekalipun,atau bahkan sedang menikmati media massa lainnya (Goug, 1999: 272).

Kecanggihan teknologi radio, juga turut serta mempengaruhi seluruh aspek kehidupan manusia, termasuk di dalamnya kegiatan dakwah. Dengan mengetahui kelebihan radio, maka alat tersebut dapat digunakan sebagai media dakwah, sebab sangat diharapkan bahwa dakwah yang dilakukan melalui siaran-siaran di radio dapat berjalan dengan efektif dan efisien sebagai salah satu pola penyampaian informasi dan upaya transfer ilmu pengetahuan. Ciri utama yang paling jelas dimiliki media massa bahwa institusi ini dirancang untuk dapat menjangkau masyarakat luas. Potensi audien dipandang sebagai kumpulan orang dalam jumlahbesar yang memiliki sifat tidak saling mengenal satu sama lain. Begitu pula hubungan antara pengirim pesan (sender) dan penerima pesan (receiver), adalah tidak saling mengenal (M.A, 2005: 9).

Berdasarkan hal diatas, maka tidak heran jika para penyampai dakwah Islam saat ini memanfaatkan media massa sebagai sarana atau alat dalam berdakwah. Pada perkembangan radio saat ini, banyak program siaran yang memuat materimateri dakwah, namun mayoritas program tersebut diperuntukan untuk kalangan remaja hingga dewasa.Dengan berbagai konsep menarik, sehingga tidak kalah menariknya dengan program-program hiburan. Bahkan saat ini ada beberapa radio yang khusus sebagai radio dakwah, salah satunya ialah Radio Rodja 75,6 AM Bogor yang menyajikan program dakwah untuk anak-anak.

Dengan format siaran dakwah, Radio Rodja hadir dalam upaya memperjuangkan kebaikan Ummat Islam melalui radio. Perkembangan era 
globalisasi dunia yang begitu pesat disertai berbagai permasalahan yang kompleks menimbulkan ketertekanan psikologi yang sangat mempengaruhi ketenangan batin, begitu pula menimbulkan efek negatif yang meresahkan perkembangan kehidupan moral masyarakat. Menurut Abu Zuhri selaku penanggung jawab program bahwa keprihatinan terhadap situasi tersebut menjadi motivasi bagi radio Rodja untuk berpartisipasi dalam memberikan kontribusi di tengah masyarakat, membangun Ummat di atas Pondasi pemahaman Agama Islam dengan benar.

Banyaknya radio di Indonesia yang mengudara dengan menyajikan bermacam-macam hiburan ke pendengar, mendorong Radio Rodja untuk ambil bagian dengan memberikan hiburan yang berbeda dengan radio pada umumnya, yakni melalui program siaran 24 jam non stop yang bernuansa Islami seperti: Murottal Al-Qur'an, Ceramah Agama, Kajian Ilmiah, Hadist dan Seputar Islam, Resensi Buku, dan majalah Islami, Ensiklopedia yang sangat sarat dengan edukasi dan informasi, serta berbagai format acara yang menarik dan variatif lainnya.

Salah satu programnya adalah, Program dakwah Kisah Menawan Sang Teladan yang bersegmentasi dakwah terhadap anak-anak, berdurasi 90 menit yang disiarkan pada hari Minggu pagi oleh Radio Rodja 75,6 AM ini dipandu oleh seorang penyiar dan seorang ustadz yang dikemas dengan pengetahuan tentang kisah-kisah perjuangan Rasulullah SAW melalui metode mendongeng dengan bahasa yang sederhana, sehingga dapat dengan mudah dipahami. Masih bertahannya program dakwah ini melalui radio, dapat dibuktikan dengan eksistensi kehadiran radio rodja dalam menyiarkan program-program atau acaraacara religius kepada seluruh aspek usia selama kurun waktu 7 Tahun. Perumusan masalah pada penelitian ini adalah :1) Bagaimana proses pra produksi Program Kisah Menawan Sang Teladan? 2) Bagaimana proses pelaksanaan produksi Program Kisah Menawan Sang Teladan? 3) Bagaimana proses evaluasi dalam Program Kisah Menawan Sang Teladan di Radio Rodja?

\section{B. Landasan Teori}

1. Pengertian Radio

Secara etimologis radio adalah pengiriman suara atau bunyi melalui udara atau seperangkat elektronik, yang berfungsi sebagai penerima isyarat 
panggilan atau pemberitahuan dari seseorang yang disampaikan lewat frekuensi gelombang radio (KBBI. 2005:919) Sedangkan menurut Kamus Besar Bahasa Indonesia, radio adalah siaran (pengiriman) suara atau bunyi melalui udara (KBBI. 2007:919). Radio adalah suara yang merupakan modal utama terpaan radio kepada khalayak, dan stimulasi yang dikoneksikan kepadanya kepada khalayak (Masduki. 2005:16). Pencampuran mengajak seperti berada dilokasi yang sedang dikomunikasikan. Dengan kemampuan tersebut radio mampu membuat para pendengarnya menciptakan "theater of mind" dalam pikiran pendengar (Burhan. 2001:131). Sedangkan dalam pendapat lain, menyatakan bahwa radio adalah keseluruhan sistem gelombang suara yang dipancarkan dari stasiun dan kemudian dapat diterima oleh berbagai pesawat penerima baik di rumah, di kapal, maupun di mobil, dan sebagainya. Radio merupakan media komunikasi yang dimanfaatkan untuk mengirim warta atau pesan jarak jauh yang dapat ditangkap oleh sekelompok orang mendengarkan melalui pemancar radio yang diinginkan.Radio juga dianggap sebuah perkembangan teknologi, yang memungkinkan suara disiarkan secara serempak melalui gelombang radio di udara (Antonius. 1998:69). Maka dapat disimpulkan bahwa radio adalah media komunikasi massa yang dapat mengirimkan suara atau bunyi melalui siaran gelombang atau frekuensi yang bisa dinikmati melalui indera pendengaran. Radio memiliki sejumlah fungsi diantaranya seperti menyebarkan informasi, mendidik, membujuk dan menghibur.

Radio juga dapat menciptakan gambar dalam imajinasi pendengar dengan kekuatan suara dan kata-kata dari sang penyiar. Siaran radio merupakan seni memainkan imajinasi pendengar melalui kata dan suara, musik dan efek lainnya yang mampu menciptakan suatu gambaran, yang semua itu dikenal dengan konsep theater of mind (A. Ius Y, 32). Sebagai medium komunikasi, radio memiliki tiga kekuatan. Pertama, mobilitas radio yang tinggi dimana radio dapat membawa pendengarmnya kemana-mana, sambil mengerjakan aktivitas lain pun, seorang dapat mendengarkan radio. Kedua, realitas radio menggiring pendengar kedalam kenyataan dengan suara-suara dan bunyi dari fakta yang terekam dan disiarkan. Ketiga, 
kesegeraan radio menyajikan informasi dan petunjuk yang dibutuhkan pendengar secara cepat, bahkan secara langsung saat kejadian.

2. Sejarah Perkembangan Radio

Sejarah dan media penyiaran dunia dimulai ketika ahli fisika jerman bernama Heinrich Hertz pada tahun 1887 berhasil mengirim dan menerima gelombang radio. Upaya Hertz itu kemudian dilanjutkan oleh Guglielmo Marconi (1874-1973) dari italia yang sukses mengirimkan sinyal morse berupa titik dan garis kepada suatu alat penerima. Sinyal yang dikirim Marconi itu berhasil menyebrangi samudra atlantik pada tahun 1901 dengan menggunakan gelombang elektromagnetik (Santi. 2008:8). Seiring perkembangannya, Radio ditemukan oleh Marchese Guglielmo Marconi tahun 1894 yang pada awalnya hanya dapat membunyikan bel dalam jarak sekitar sepuluh meter. Sejalan dengan itu perkembangan radio sebagai media komunikasi terus mengalami perkembangan hingga diliputi dengan meningkatnya pendirian stasiun radio.

Perkembangan radio pun terus-menerus terjadi sampai pada tahun 1930-an, dimana pada saat itu Edwin Howard Amstrong berhasil mengembangkan pesawat penerima radio yang menggunakan frekuensi modulasi (FM) menjadi dasar bagi pesawat radio modern saat ini. Radio FM memiliki kualitas suara lebih bagus, jernih, dan bebas dari gangguan siaran (Morrisan. 2008:4). Radio pada awalnya digunakan kebanyakan oleh maritim. Yaitu untuk mengirim pesan telegraf menggunakan kode Morse antar kapal dan darat. Salah satu pengguna awalnya adalah Angkatan Laut Jepang yang mematamatai armada Rusia saat perang Tsushima tahun 1901. Salah satu penggunaan yang paling dikenang adalah pada saat tenggelamnya kapal penumpang Inggris RMS Titanic pada 1912, termasuk komunikasi antara operator di kapal yang sedang tenggelam dan kapal terdekar, dan komunikasi ke stasiun darat mendaftar yang terselamatkan.

Radio digunakan untuk menyaurkan perintah dan komunikasi antara Angkatan darat dan Angkatan Laut di kedua pihak pada Perang Dunia II. Jerman menggunakan komunikasi radio dan pesan diplomatik ketika kabel bawah lautnya dipotong oleh pihak Britania. Amerika Serikat menyampaikan 
14 pokok pikiran Presiden Woodrow Wilson kepada jerman melalui radio ketika perang. Siaran radio mulai dapat dilakukan pada tahun 1920-an, Seiring populernya pesawat radio, terutama di Eropa dan Amerika Serikat. Selain siaran, siaran titik ke titik, termasuk telepon dan siaran ulang program radio, mulai popular antara 1920-an dan 1930-an. Pada saat "arek-arek Suroboyo" dengan gagah berani menantang pendaratan Sekutu yang dibonceng tentara pendudukan Belanda, melalui corong RRI Surabaya, Bung Tomo dengan pekik "Merdeka"-nya yang terkenal itu mampu menggugah semangat juang bangsa Indonesia untuk bangkit secara patriotik hanya dengan bersenjatakan bambu runcing, membela Tanah Air Indonesia. Penggunaan radio pada masa perang adalah pengembangan pendeteksian dan pelokasian pesawat dan kapal dengan mengggunakan radar (radio detection and ranging). Sekarang, radio mengalami perkembangan bentuk yang amat beragam, termasuk jaringan tanpa kabel, komunikasi bergerak di segala jenis, dan penyiaran radio. Sebelum televisi menjadi terkenal, siaran radio komersil mencangkup drama, komedi, beragam show dan banyak hiburan lainnya, tidak hanya berita dan musik saja (Hasan. 2012:122).

\section{Metode Penelitian}

Penelitian ini menggunakan pendekatan kualitatif. Metode penelitian kualitatif juga penelitian yang berlandaskan pada filsafat postpositivisme, dimana peneliti adalah instrument kunci, teknik pengumpulan data dilakukan secara triangulasi (gabungan), analisis data bersifat induktif/kualitatif, dan hasil penelitian kualitatif lebih menekankan makna dari pada generalisasi (Sugiyono. 2013:9).

Metode penelitian yang digunakan oleh penulis adalah analisis deskriptif. subjek dalam penelitian ini adalah radio Rodja 75,6 AM Bogor, sedangkan yang menjadi objek dalam penelitian ini adalah produksi Program Kisah Menawan Sang Teladan di Radio Rodja75,6 AM Bogor yaitu pra produksi, produksi, dan pasca produksi. Teknik pengumpulan data yang dilakukan adalah melalui observasi dengan melakukan pengamatan langsung mengenai produksi Program Kisah Menawan Sang Teladan di Radio Rodja 75,6 AM Bogor dengan 
mengadakan kunjungan langsung ke kantor dan studio Rodja 75,6 AM yang beralamat di Jl. Pahlawan Kp. Tengah Rt.03/03 Cileungsi, Bogor, melakukan wawancara secara mendalam kepada Programm Director dan Penyiar dan dokumentasi.

Penelitian ini menganalisis proses produksi mulai dari tahapan pertama, yaitu pra produksi yang terdiri dari penemuan ide. Tahapan ini dimulai ketika seorang produser menemukan idea atau gagasan dalam membuat riset dan menuliskan naskah atau meminta penulis naskah atau mengembangkan gagasan menjadi naskah sesudah riset. Kemudian perencanaan yang meliputi jangka waktu kerja (time schedule), penyempurnaan naskah, pemilihan penyiar, estimasi biaya, penyediaan biaya, waktu siaran, dan rencana lainnya yang merupakan bagian dari perencanaan yang perlu dibuat secara hati-hati dan teliti. Terakhir persiapan yang meliputi semua hal dalam perencanaan, latihan penyiar, dan pembuatan setting suara, meneliti dan melengkapi semua peralatan yang diperlukan. Semua persiapan ini paling baik diselesaikan menurut jangka waktu kerja yang sudah ditetapkan (Wibowo. 2007:39). Kemudian tahapan ke dua adalah produksi. Proses produksi juga ada yang dilaksanakan secara off air atau rekaman suara siaran, selain itu ada juga produksi yang dilakukan secara relay. tahapan ke tiga adalah pasca produksi yaitu proses evaluasi setelah sebuah program selesai disiarkan kepada pendengar.

\section{Hasil}

Dalam suatu program di radio memiliki beberapa proses yang harus dilalui sesuai dengan Standart Operational Procedure (SOP) yang terdiri dari 3 tahap penting, yaitu Pra Produksi (penemuan ide, perencanaan, dan persiapan), Produksi (pelaksanaan proses siaran program) dan Pasca produksi (evaluasi pada program acara setelah produksi). Merujuk pada penjelasan di atas, maka program Kisah Menawan Sang Teladan di Radio Rodja 75,6 AM melalui tiga tahapan, yaitu :

1. Pra Produksi

Sebelum acara dimulai, tim produksi yakni produser, operator produksi, penyiar, dan narasumber harus sudah stand by lebih kurang 30 menit untuk melakukan persiapan produksi dan untuk meminimalisir 
kesalahan saat produksi. Untuk menarik minat pendengar, operator member informasi melalui media online, seperti Facebook, Twitter bahwa program Kisah Menawan Sang Teladan mulsi disiarkan. Operator produksi mempersiapkan alat siaran seperti mixer, microphone, earphone, dan komputer yang menunjang ketika proses produksi siaran berlangsung.

a. Pencarian Ide dan Nama Program

Radio rodja banyak menampung ide-ide, baik yang datang dari tim produksi, para pembina, penasihat, bahkan melalui pendengar langsung. Setelah itu, tim penanggung jawab program akan mengolah, mendiskusikan, dan mempertimbangkan usulan program tersebut dengan berbagai unsur. Dalam setiap ide pembahasan acara, pihak radio biasanya menyerahkan kepada penyiar sebagai pengisi acara untuk menentukan pembahasan pada setiap minggunya. Misalnya Abu Lukman selaku penyiar pertama akan mengkisahkan kisah-kisah para Nabi, sedangkan Kang Odja selaku penyiar kedua akan membahas kisah sahabat.

Audien tidak saja melihat suatu program dari penampilannya semata namun juga hal-hal yang berada di luar itu. Audien juga akan mempertimbangkan aspek-aspek, seperti kualitas, nama, kemasan program dan bahkan perusahaan yang berada di belakang suatu program dan media bersangkutan. Dalam hal ini terdapat dua hal yang sangat terkait dengan program sebagai suatu produk yaitu merek dan kemasan. Nama Program, dalam memilih nama suatu program, pengelola program harus memilih nama yang dapat menginformasikan konsep program yang dapat membantu menempatakan atau memposisikan program di memori otak audien.

b. Format Program

Program Kisah Menawan Sang Teladan ini menggunakan format interactive, yaitu baik penyiar, pendengar, dan narasumber akan berinteraksi baik dalam segmen Kisah Menawan Sang Teladan maupun segmen Bimbingan Tilawah Al-Qur'an. Pendengar dapat juga berkomunikasi melalui line telephone untuk memberikan pelajaran atau hikmah dari cerita yang disampaikan oleh penyiar. 
c. Materi

Untuk menentukan materi yang dibawakan pada setiap siaran acara Kisah Menawan Sang teladan, penyiar selaku pengisi acara menentukan sendiri materi yang akan dibahas pada setiap minggunya, namun dengan diskusi dengan pembina dan penasihat untuk mencegah kesalahan, serta mendapatkan masukan atau saran dari para ustadz.

d. Pengisi Acara

Abu Lukman adalah penyiar Program Kisah Menawan Sang Teladan di Radio Rodja 75,6 AM. Beliau sudah menjadi penyiar, mulai dari awal pembangunan radio yang hanya komunitas, hingga bisa dinikmati seluruh Indonesia. Beliau juga sebagai pembawa acara televisi di Tv Rodja selama dua tahun, dalam dua program kajian islam. Narasumber Program Kisah Menawan Sang Teladan di Radio Rodja 75,6 AM yakni Utadz Abu Unaish Ali Subhana. Beliau memiliki banyak pengalaman dalam mencetak penghafal Al-Qur'an dari mulai anak-anak, hal ini bisa diketahui dengan beliau menjadi pengajar dalam pesantren dibawah naungan Radio Rodja

e. Waktu Siaran

Program Kisah Menawan Sang Teladan disiarkan setiap hari Minggu, selama 90 Menit mulai dari pukul 07.30-09.00 WIB, live dari studio di Rodja 75,6 AM.

\section{f. Biaya Produksi}

Sumber biaya produksi acara Kisah Menawan Sang Teladan ini bersumber dari para donator, para pembina dan penasihat, juga hasil penjualan buku yang diterbitkan oleh ustadz-ustadz di Radio Rodja 75,6 AM.

2. Produksi

Dalam proses produksi program acara Kisah Menawan Sang Teladan dilibatkan seorang produser, operator produksi, penyiar, dan narasumber. Keempat komponen ini sangat berpengaruh terhadap jalannya produksi acara. Jika salah satu saja dari mereka tidak ada, maka produksi tidak akan berjalan baik dan lancar. 


\section{a. Pelaksanaan Siaran}

Penyiar bertugas untuk membuka, membacakan kisah teladan, berinteraksi kepada pendegar, sebagai moderator dalam segmen bimbingan tilawah Al-Qur'an, dan sebagai penutup acara. Dalam hal ini penyiar harus memiliki sifat luwes dan kemampuan berkomunikasi yang bagus. Kriteria lain, penyiar harus memiliki wawasan keilmuwan tentang agama islam yang cukup, karena acara yang dibawakan bermuatan dakwah. Operator produksi bertugas menyiapkan dan mengoperasikan segala alat yang dibutuhkan ketika proses siaran berlangsung. Produser acara tentunya bertugas mengawasi jalannya acara, untuk meminimalisir kesalahan selama proses produksi berlangsung.

b. Materi Produksi

Materi yang disampaikan dalam program acara Kisah Menawan Sang Teladan ini adalah mengenai kisah perjuangan para Nabi, Sahabat Nabi, dan kisah Ulama terdahulu dalam meperjuangkan agama Islam. Kisah tersebut dikemas secara menarik, dengan bahasa yang sederhana, dan berdasarkan sumber yang shahih serta dengan tafshiyah kepada para penasihat terlebih dahulu.

c. Pelaksana Produksi

Produser dan Program Director adalah Abu Zuhri, pemyiar dan pengisi acara adalah Abu Lukman dan Kang Oja, narasumber dalam segmen bimbingan tilawah Al-Qur'an adalah Ustadz Abu Unaish Subhana dan operator produksi adalah Ka Dani dan Ka Ari.

d. Sarana dan Pra Sarana Produksi

Adapun beberapa peralatan yang digunakan dalam proses produksi acara Kisah Menawan Sang Teladan, yakni mixer, pemancar radio (microphone, earphone, recorder, computer). Sedangkan prasarana penunjang produksi di studio siaran, diantaranya ruang studio yang nyaman, ruangan yang tidak bising dan kedap suara, dan property pendukung seperti sofa, meja dan mini panggung. 
e. Set up dan Rehearsal

Dalam acara Kisah Menawan Sang Teladan di Radio Rodja 75,6 AM, set up dan rehearsal terkadang dilakukan oleh tim produksi. Untuk set up atau persiapan yang bersifat teknis, biasanya tim produksi melakukannya setegah jam sebelum acara dimulai yaitu, jam 07.00 WIB. Mereka hanya mengecek persiapan peralatan seperti, mixer, earphone, microphone, computer serta peralatan lainnya.

\section{Pasca Produksi}

Pasca produksi merupakan tahapan terakhir dari seluruh rangkaian proses produksi sebuah acara di radio. Pada tahap ini dilakukan evaluasi acara mulai dari awal hingga akhir siaran setiap minggunya. Tujuan diadakannya evaluasi ini adalah untuk mengetahui sejauh mana kesuksesan sebuah program acara dan kendala apa saja yang biasa terjadi. Pada program Kisah Menawan Sang Teladan ini terdapat dua cara evaluasi, yaitu evaluasi langsung dan evaluasi keseluruhan program dalam rapat setiap pekannya. Evaluasi langsung dilakukan ketika terjadi kesalahan dalam penyampaian kisahnya, maupun kesalahan tata gerak kamera dan kualitas suara yang dihasilkan di radio. Sedangkan evaluasi keseluruhan, membahas permasalahan dan kesalahan pada saat siaran setiap minggunya.

Evaluasi besar diadakan dalam setiap 6 bulan sekali, tujuannya untuk mengadakan perubahan atau penambahan acara atau merekrut sumber daya manusia baru. Setiap melakukan evaluasi, yang menjadi pembahasannya adalah kinerja personil, kerjasama tim, evaluasi sejauh mana respon positif dari pendengar dan pengaruhnya, evaluasi tema-tema yang cukup popular dan cocok bagi pendengar, dan evaluasi program siaran (termasuk penyiar, operator, dan materi siarannya). Pada tahap ini juga selalu dibahas mengenai strategi apa yang bisa digunakan untuk mengembangkan program acara untuk tetap diminati pendengar anak-anak setia radio rodja 75,6 AM. Evaluasi adalah bagian penting dari produksi agar acara bisa mencapai target dan bisa memperkecil kendala yang biasa terjadi. 


\section{E. Pembahasan}

\section{Proses Produksi Siaram Radio}

a. Acuan Dasar Siaran Radio

Acuan dasar di bawah ini merupakan hal yang sangat penting didalam merencanakan, memproduksi, dan menyiarkan suatu acara bagaimanapun bentuk dan sifatnya. Ada lima acuan dasar yang sangat penting, yaitu ide, pengisi acara, peralatan, satuan kerja produksi, dan pendengar. Ke lima satuan ini satu sama lain tidak dapat dipisahkan, akan saling terkait dengan yang lainnya dan saling melengkapi agar tercipta hasil produksi yang lebih baik.

1) Ide

Ide merupakan sebuah rencana dimana pada rencana tersebut akan disusun pesan-pesan yang akan disampaikan kepada komunikan (pendengar), melalui medium radio dengan tujuan tertentu.

\section{2) Pengisi Acara}

Pengisi acara terdiri dari penyiar, bintang tamu, artis, tokoh, pakar, cendikiawan, ulama dan sebagainya yang memiliki kemampuan tertentu dalam bidangnya untuk tampil dalam sebuah acara siaran.

3) Peralatan

Setidaknya sebuah studio harus dilengkapi dengan perlengkapan misalnya, seperangkat mixer audio, audio player (untuk memainkan musik), speaker (pengeras suara), turn table, ear phone, microphone, computer, monitor, dan alat komunikasi yang dapat berhubungan dengan ruang operator.

4) Organisasi Pelaksana Produksi

Kelompok kerja produksi dibagi menjadi tiga satuan kerja yang terdiri dari satuan kerja produksi/siaran, satuan kerja fasilitas produksi dan satuan kerja teknis atau operator teknik (engineering).

\section{5) Pendengar}

Mereka adalah sasaran dari setiap acara yang disiarkan dan mereka merupakan faktor yang ikut menentukan berhasil atau tidaknya acara yang telah disiarkan. 


\section{b. Tahapan Produksi}

Tahapan pelaksanaan produksi suatu program acara, baik di radio maupun di televisi, pasti melibatkan banyak orang dan juga banyak peralatan, serta biaya produksi yang tidak sedikit. Selain membutuhkan organisasi yang terstruktur, didalamnya juga diperlukan tahap pelaksanaan produksi yang lazim disebut Standard Operation Procedure (SOP).

1) Pra Produksi

Tahap ini sangat penting, sebab jika tahap ini dilaksanakan dengan rinci dan baik, sebagian pekerjaan dari produksi yang direncanakan sudah selesai. Tahap pra produksi meliputi tiga bagian, yaitu penemuan ide, perencanaan, dan persiapan.

2) Produksi

Produksi adalah seluruh kegiatan siaran, baik di dalam studio maupun di luar studio, baik dari tahap set up sampai selesai (TVRI. 2008).

\section{3) Pasca Produksi}

Pasca produksi adalah proses evaluasi setelah sebuah program selesai disiarkan kepada pendengar. Proses evaluasi terdiri dari analisa isi acara (materi yang disampaikan, kecakapan penyiar), analisa isi kemasan (pemandu, kualitas audio, durasi), dan pembenahan dan acara (pengembangan acara selanjutnya).

\section{Dakwah Melalui Radio}

Dakwah melalui radio merupakan hal yang sudah tidak asing, banyak kita temukan radio yang menyiarkan dakwah, baik yang membahas masalah tauhid, fiqih, sampai dengan masalah keluarga dalam pandangan islam. Kebaradaan radio ini dalam dunia dakwah, sangat membantu syi'ar agama kepada objek dakwah yang tersebar di wilayah yang berbeda-beda.

Dalam kegiatan da'wah keberadaan radio sangat penting dalam penyampaian materi da'wah dalam bentuk-bentuk pidato dan ceramah atau kuliah. Radio menjangkau mad'unya dalam jarak jauh dan meluas. Oleh karena itu radio merupakan media yang efektif dalam penyampaian da'wah untuk semua kalangan. Kelebihan da'wah melalui radio terletak pada efektifitas dan efisiensi 
berda'wah. Hal ini Nampak dari adanya bentuk yang sederhana tanpa harus ketemu antara da'I dan mad'unya (Ghazali. 1997:37).

Namun kini "perkembangan masyarakat yang semakin meningkat, tuntutan yang sudah semakin beragam, membuat dakwah tidak bisa lagi dilakukan secara tradisional. Laju perkembangan zaman memacu tingkat kemajuan ilmu dan teknologi komunikasi sebagai sebuah sarana yang dapat menghubungkan suatu masyarakat di satu tempat dengan masyarakat di tempat lain. Dan kecanggihan itu teknologi yang ikut mempengaruhi aspek kehidupan manusia (Ghazali. 1997:33).

\section{Profil Radio Rodja 75,6 AM Bogor}

Radio Rodja dimulai dari sebuah radio FM komunitas yang dirintis oleh ustadz Badrusalam sejak awal 2005. Kemudian, dari animo masyarakat yang besar akan hadirnya Radio Rodja, sehingga Radio Rodja untuk secara resmi mengudara pada frekuensi $756 \mathrm{kHz}$ (AM) di tahun 2007. Dalam perkembangannya, sejak mengudara dengan frekuensi 756 AM ini, Radio Rodja mengalami kemajuan pesat, karena karakteristik dari sinyal AM ini yang memiliki salah satu kelebihan paling utama yaitu daya jangkauanya yang jauh lebih luas daripada sinyal FM.

Radio yang mempunya visi menjadi media dakwah Islam istiqomah menyampaikan Tashfiyah dan Tarbiyah dengan senantiasa merujuk kepada pemahaman generasi Islam yang pertama dan utama ini didirikan oleh ustadz Badrusalam menyajikan siaran tilawah Al-Qur'an Al-Karim, hadits-hadits Nabi SAW, kajian Islam Ahlus Sunnah wal Jama'ah, juga nasihat para ulama Ahlus Sunnah, yang sesuai dengan pemahaman para sahabat Nabi SAW. Sekarang ini, siaran Rodja dapat dinikmati melalui radio frekuensi 756 AM (Jabodetabek dan stasiun relay Rodja di Bandung, Berau, Lampung, Pontianak, dan Tanjung Pinang), radio streaming, radio via Flexi (Flexi Radio), radio satelit dan TV salelit (membutuhkan perangkat antena parabola), dan TV streaming.

\section{Sekilas Mengenai Acara Kisah Menawan Sang Teladan}

Acara Kisah Menawan Sang Teladan yang sudah kurang lebih 7 tahun berjalan, merupakan jawaban atas kekhawatiran akan kondisi saat ini, untuk mencegah pengrusakan moral secara langsung maupun tidak langsung. Acara ini mengkisahkan perjuangan Nabi dan Para Sahabat dalam mendakwahkan Islam 
kepada keluarga, kaumnya, dan kepada kaum bangsa lain. Dengan menggunakan konsep mendongeng, menggunakan bahasa yang sederhana membuat acara ini secara antusias disambut oleh pendengar khususnya anak-anak. Tujuan dari acara kisah menawan sang teladan ini adalah untuk memperkenalkan kisah-kisah sang teladan (Nabi dan Sahabat) kepada setiap pemirsanya, agar tumbuh rasa cinta, rasa kagum, dan ingin mencontoh dalam kehidupan sehari-hari.

Radio rodja berupaya menyajikan program-program yang 1) sesuai dengan syariat, 2) Menyajikan program tersebut di atas pemahaman ulama ahlusunnah dari generasi ke generasi, berdasarkan Al-Qur'an, berdasarkan sunnah yang shahihah, dan juga pemahaman yang benar. 3) program kisah menawan sang teladan ingin memperkenalkan sosok ulama-ulama ahlusunnah, untuk mendekatkan kaum muslimin, kepada ulamanya, kepada generasi pertama yang telah memegang kejayaan agama Islam.

Program ini mengudara setiap hari minggu pagi, dengan durasi sekitar 90120 menit. Pemilihan jadwal siaran ini mempertimbangkan objek dakwah yaitu anak-anak, agar mereka dapat ikut mendengarkan dan berpartisipasi dalam program tersebut. Karena pada hari minggu, anak-anak mempunyai waktu luang, dan tidak mengganggu kegiatan utamanya jika sudah bersekolah. Dalam program ini dipandu oleh satu pengisi acara (penyiar) secara bergantian (Abu Lukman dan Kang Odja) setiap minggu, yang akan menceritakan kisah teladan para Nabi, Rasul, dan Sahabat. Mereka akan menyampaikan cerita tersebut dengan bahasa yang sederhana, penuh ekspresi (seperti ketika menceritakan dialog antara Nabi Ibrahim kepadaIsmail tentang perintah menyembelihnya, disampaikan oleh Abu Lukman dengan seperti menjadi 2 tokoh tersebut).

Pada sesi berikutnya dihadirkan satu narasumber yang akan memandu bimbingan tilawah Al-Qur'an yakni ustadz Ali Subhana. Dalam sesi tersebut, ustadz Ali akan memberikan arahan bagaimana tata cara pengucara huruf demi huruf Al-Qur'an dalam buku pedomannya. Seperti kaidah pengucapannya, baik tebal maupun tipisnya, jelas atau samarnya, hingga panjang atau pendeknya. Ustadz ali juga akan mengkoreksi bacaan anak-anak tersebut, kemudian dibimbing hingga sesuai dengan kaidah yang baik dan benar. Setelah bimbingan tersebut benar, maka akan dilanjutkan dengan hafalan surah Al-Qur'an, satu anak 
menyetorkan hafalan 10-15 ayat setiap pertemuan atau ketika melalui telepon. Pada akhir program kisah menawan sang teladan ini, penyiar dan narasumber memberikan pengulangan kembali pelajaran dari kisah pada sesi pertama, dan mengingatkan kembali tata cara membaca huruf dalam Al-Qur'an. Hal ini bertujuan untuk mengingatkan kepada anak-anak agar lebih menerapkannya dalam kehidupan, serta dalam membaca Al-Qur'an.

\section{F. Kesimpulan}

Berdasarkan uraian di atas dapat disimpulkan bahwa, dalam program kisah menawan sang teladan melalui beberapa tahap yaitu pra produksi meliputi: ide, perencanaan format, materi siaran, pengisi acara, nama program, dan waktu siaran. Proses produksi meliputi: pelaksanaan siaran, materi produksi, pelaksana produksi, serta sarana dan prasarana. Pasca produksi yaitu evaluasi. Proses produksi meliputi: pelaksanaan siaran, materi produksi, pelaksana produksi, pengawasan, serta sarana dan prasarana. Pasca produksi yaitu evaluasi, yakni menyoroti bagian penyampaian, kemudian dari sisi kualitas audio (suara), hostnya, materi pembahasan, penataan ruang, penataan kamera, komunikasi antara host dengan pemirsa, bahkan kritik dari pendengar.

Program kisah menawan sang teladan ini merupakan program dakwah yang bersegmentasi usia anak-anak, dimana dewasa ini sangat jarang kita menemui program acara dakwah anak khususnya melalui media radio. Mayoritas acara anak-anak juga hanya bersifat menghibur, bahkan tidak jarang bersifat tidak mendidik. Latar belakang program acara ini adalah karena suatu hal yang bisa mempengaruhi pola pemikiran anak adalah orang-orang yang ada di sekitarnya. Terutama orang tua yang mengasuh anak tersebut. Komunikasi yang dijalin dengan anak akan bisa direkam dengan baik oleh anak yang kemudian dicerna oleh akalnya. Gaya bicara dan gaya komunikasi inilah yang nantinya berperan besar dalam membentuk pola pemikiran anak.Untuk membantu mengembangkan pola pemikiran anak maka kita sebagai orang tua bisa melakukan cara-cara sederhana namun memiliki dampak yang bagus untuk pemikiran anak.

Dalam pemilihan kisah dan dongeng sebaiknya para orang tua menghindari cerita yang berisi banyak kebohongan dan tidak masuk diakal. Pilihlah cerita yang 
bisa memberi inspirasi dan manfaat untuk anak, agar anak bisa berkaca pada cerita tersebut dan mempraktekkan dalam kehidupan sehari-hari karena cerita yang didengarnya adalah nyata dan tidak sulit untuk menirunya. Contoh cerita yang bisa diterapkan adalah cerita tentang kisah Nabi-nabi, para pendahulu yang shaleh, salah satu contohnya adalah cerita tentang nabi Ibrahim,nabi ismail, sahabat seperti Salman Al-Farisi dll. Kisah-kisah tersebut bisa menginspirasi dan akan membentuk pola pemikiran anak. Dalam program acara Kisah Menawan Sang Teladan ini dikemas dengan bahasa yang sederhana oleh penyiar, disampaikan dengan penuh ekspresi, dan interaktif antara penyiar dengan anakanak. Sehingga secara tidak langsung akan menjadi stimulus bagi para anak-anak untuk mengikuti apa yang diceritakan oleh penyiar. Hal ini merupakan usaha untuk menumbuhkan kecintaan dan semangat meneladani Tokoh-Tokoh Islam yang relevan untuk dijadikan teladan. Karena untuk membentuk karakter manusia yang baik, haruslah dimulai dari sejak anak-anak salah satunya dengan mengajak anak-anak menyaksikan acara Kisah Menawan Sang Teladan ini.

\section{Daftar Pustaka}

Antonius, Darmanto, 1998. Teknik Penulisan Naskah Acara Siaran Radio, Yogyakarta : Atmajaya

A. Ius Y. Triartanto, Broadcasting Radio:Panduan Teori dan Praktek, Yogyakarta : Pustaka Book Publisher

Bahasa, T. P. K. P. 2005. Kamus Besar Bahasa Indonesia (3rd ed.). Jakarta: Balai Pustaka.

Bungin, B. 2011. Sosiologi Komunikai Teori, Paradigma, dan Diskursus Teknologi Komunikasi di Masyarakat. Jakarta: Kencana.

Burhan, Bungin, 2011. Sosiologi Komunikai Teori, Paradigma, dan Diskursus Teknologi Komunikasi di Masyarakat Jakarta : Kencana

Darmanto, A. 1998. Teknik Penulisan Naskah Acara Siaran Radio (2nd ed.). Yogyakarta: Atmajaya.

Djamaludin, Abidin, 1996. Komunikasi dan Bahasa Dakwah, Jakarta: Gema Insani Press.

Fred, Wibowo, 2007. Teknik Produksi Program Televisi, Yogyakarta: Pinus Book Publisher.

Ghazali, M. B. 1997. Da’wah Komunikatif (1st ed.). Jakarta: CV. Pedoman Ilmu Jaya.

Goug, H. 1999. Perencanaan Penyajian Produksi Program Radio. Jakarta: Pengurus Pusat HPPI/ Himpunan Praktisi Penyiaran Indonesia. 
Hasan, Asy’ari Oramahi. 2012. Jurnalistik Radio Kiat Menulis Berita Radio, Jakarta:Erlangga,

Kamus Besar Bahasa Indonesia. 2007. Edisi Ketiga, Jakarta: Balai Pustaka.

Karlinah. 1999. Buku Materi Pokok Komunikasi Massa, Jakarta: Universitas Terbuka.

M.A, M. 2005. Media Penyiaran Strategi, Mengelola Radio dan Televisi (1st ed.). Jakarta: Ramadina Prakasra.

Masduki. 2005. Menjadi Broadcaster Profesional Yogyakarta: PT.LkiS

Masduki. 2004. Menjadi Broadcaster Profesional (1st ed.). Yogyakarta: LKiS.

Morrisan. 2008. Manajemen Media Penyiaran Strategi Mengelola Radio dan Televisi akarta: Kencana.

Redi Panuju, Nalar. 2005. Jurnalistik: Dasarnya Dasar Jurnalistik, Bayumedia Publising,

Santi Indra Astuti. 2008. Jurnalisme Radio Komunikasi dan Praktek, (Bandung: Simbiosa Rekatama Media.

Saputra, W. 2011. Pengantar Ilmu Dakwah (1st ed.). Jakarta: PT. Raja Grafindo Persada.

Sugiyono. 2013. Metode Penelitian Kuantitatif, Kualitatif dan R\&D. Bandung: ALFABETA.

TIM Penyusun Kamus Pusat Bahasa, 2005. Kamus Besar Bahasa Indonesia, (Jakarta: Balai Pustaka

Tommy Supapto, 2006. MS, Berkarir di Bidang Broadcasting, (Yogyakarta: Media Pressindo.

Tommy Suprapto, 2006. Berkarir di Bidang Broadcasting, (Yogyakarta: Media Pressindo.

TVRI, D. P. 2008. Standard Operating Procedure. Jakarta: PT. TVRI.

Wibowo, F. 2007. Teknik Produksi Program Televisi. Yogyakarta: Pinus Book Publisher. 